\title{
Evidências científicas sobre atuação do enfermeiro na parada cardiorrespiratória na unidade de terapia intensiva: revisão integrativa
}

\author{
Scientific evidence about the nurse's performance in \\ cardiopulmonary arrest in the intensive care unit: integrative \\ review
}

\author{
Rodrigo Pereira Costa Taveira ${ }^{1} \bullet$ Fátima Helena do Espírito Santo ${ }^{2} \bullet$ Carla Lube de Pinho Chibante $^{3} \bullet$ \\ Thayane Dias dos Santos ${ }^{4}$ Willian de Andrade Pereira de Brito ${ }^{5}$
}

\begin{abstract}
RESUMO
Objetiva-se identificar a produção científica acerca da atuação do enfermeiro na parada cardiorrespiratória (PCR). Tratase de uma revisão integrativa, na qual foi realizado o levantamento sobre artigos publicados nos bancos de dados da: MEDLINE, LILACS, IBECS E BDENF, entre os anos de 2010-2015. A busca de estudos primários foi realizada nos meses de agosto e setembro de 2015. Foram utilizados para a busca os seguintes descritores: ressuscitação cardiopulmonar, enfermagem, equipe de assistência ao paciente e unidades de terapia intensiva. Foram identificados nove artigos que foram submetidos à análise de conteúdo. Emergiram três categorias: Ensino teórico-prático voltado para os profissionais da equipe de enfermagem; Conhecimento dos profissionais da área de saúde (equipe multiprofissional e de enfermagem) sobre PCR e ressuscitação cardiopulmonar; Desempenho da equipe multiprofissional e/ou equipe de enfermagem durante e após a PCR. Concluí-se que foi evidenciado que para um bom desempenho durante a RCP, a equipe deve ter boas condições de trabalho, como por exemplo, acessibilidade a tecnologias, como ambiente virtual para ensino, ferramentas para mensurar o nível de conhecimento dos profissionais, e estrutura física do ambiente de trabalho para melhorar o processo laboral.
\end{abstract}

Palavras-chave: Ressuscitação Cardiopulmonar; Enfermagem; Equipe de Assistência ao Paciente; Unidades de Terapia Intensiva.

\begin{abstract}
The aim is to identify the scientific literature about the nurse's performance in cardiopulmonary arrest (PCR). This is an integrative review, which was conducted a survey of articles published in the databases: MEDLINE, LILACS, IBECS E BDENF, between the years 2010-2015. The search for primary studies was held in the months of august and september 2015. Were used to search the following keywords: Cardiopulmonary Resuscitation, Nursing, Patient Care Team, Intensive Care Units. Nine articles were identified that were subjected to content analysis. Emerged three categories: Theoretical-practical targeted towards professionals in the nursing staff; Knowledge of health professionals (multi-professional team and nursing care) about PCR and Cardiopulmonary resuscitation; Multidisciplinary team performance and/or nursing staff during and after PCR. It was evidenced that for a good performance during CPR, the team must have good working conditions, like for example, accessibility to technologies, as virtual environment for training, tools for measuring the level of knowledge of professionals, and physical structure of the workplace.
\end{abstract}

Keywords: Cardiopulmonary Resuscitation; Nursing; Patient Care Team; Intensive Care Units. 


\section{INTRODUÇÃO}

Dentre as diversas situações que podem ocorrer em uma Unidade de Terapia Intensiva (UTI) e em outros ambientes hospitalares, nenhuma supera a prioridade de atendimento à uma Parada Cardiorrespiratória (PCR). Ações bem organizadas e planejadas diminuem as sequelas e influenciam nos resultados do atendimento, assim como as capacitações tornam-se importantes para identificação prévia de uma PCR 1 .

Embora a Ressuscitação Cardiopulmonar (RCP) tenha uma longa história que remonta aos tempos bíblicos e se prolonga através dos séculos. Seu "nascimento" moderno ocorreu em 1960, quando Koewenhoven, Jude e Knickerbocker publicaram seu artigo sobre o uso da compressão torácica, os quais destacaram que "tudo o que se precisa são duas mãos" e de fato escreveram sobre 14 sobreviventes em um universo de 20 tentativas em que utilizaram a compressão torácica².

Embora manobras semelhantes tenham sido descritas inúmeras vezes em períodos anteriores, naquele momento, elas assumiriam nova importância, uma vez que Safar havia feito experimentos com a ventilação boca a boca e a desfibrilação externa. 0 que restava era juntar esses três componentes-chave, o que aconteceu em setembro de 1960, em simpósio organizado pelo Corpo Docente de Medicina e Cirurgia do Estado de Maryland, onde se consagrou que "esses componentes não podiam mais ser considerados como elementos isolados, e sim como parte da abordagem completa para a ressuscitação".

Naquela época, no entanto, a RCP era considerada um procedimento exclusivamente médico, uma vez que enfermeiros e dentistas eram impedidos de executar a prática. Com isso, seu impacto era limitado, apesar do grande interesse internacional. Gradualmente, os pontos de vista foram mudando e, por volta de 1974, as grandes vantagens de envolver o público em geral tornaram-se mais evidentes quando a American Heart Association (AHA) publicou suas primeiras diretrizes destinadas tanto aos profissionais da saúde quanto aos leigos².

Em 1970, Milstein definiu a parada cardíaca como a cessação súbita e inesperada da atividade mecânica ventricular útil e suficiente em indivíduo sem doença incurável, debilitante, irreversível e crônica. Várias definições surgiram e pequenas nuanças as modificaram, porém é certo que a parada cardíaca não advém de causa única, e que sua origem deve ser investigada e diagnosticada para melhor assistir a vítima ${ }^{3}$.

Segundo a AHA, PCR é definida como irresponsividade, ausência de respiração efetiva e ausência de pulso central. A avaliação do paciente não deve ultrapassar mais de 10 segundos. Essa definição vale para o paciente adulto e pediátrico. Se houver dúvida por parte do profissional, considera-se que o paciente está em PCR. Importante salientar que não se deve apenas saber abordar um paciente com PCR, mas também reconhecer quando não iniciar as manobras de $\mathrm{RCP}^{4-5}$. No paciente pediátrico, que apresenta frequência cardíaca menor ou igual a 60 batimentos e com sinais de má perfusão (ex: enchimento capilar lentificado e cianose), também deve ser dado o alerta de $\mathrm{PCR}^{6}$.

O enfermeiro participa tanto do Suporte Básico de Vida (SBV) como do Suporte Avançado de Vida (SAV), e tem como papel a reanimação cardiorrespiratória contínua (manobras de R(P), garantir acesso venoso periférico, administração de fármacos conforme orientação médica, monitorização do ritmo cardíaco e dos outros sinais vitais, registro dos acontecimentos, notificação ao médico plantonista, sendo que o apoio para os familiares é muito importante nesta ocasião $0^{4-7}$.

Dentro do exposto até o momento, sabe-se que o atendimento à parada cardiorrespiratória envolve a necessidade de constantes avanços no conhecimento dos profissionais de enfermagem sobre os cuidados prestados, bem como exige um aperfeiçoamento da atuação da equipe multidisciplinar com a valorização dos diversos saberes. A necessidade de atitudes rápidas e precisas demonstra que é importante manter-se atualizado diante das novas diretrizes no atendimento de pacientes em $P C R$, independente da especialidade desse profissional de saúde ${ }^{8-9}$.

Os profissionais de enfermagem, geralmente, são os primeiros a detectarem uma PCR e devem iniciar as manobras de SBV enquanto aguardam a chegada da equipe de suporte avançado. A aplicação imediata, competente e segura das manobras de reanimação cardiopulmonar, por parte dos profissionais que primeiro detectam essa situação, é fator que contribui para o sucesso do atendimento e consequente sobrevida da vítima de $\mathrm{PCR}^{10}$.

Frequentemente, a equipe de enfermagem detecta os sinais de PCR, dispara o chamado de emergência, entretanto não inicia as manobras de reanimação cardiopulmonar, limitando-se a levar o equipamento de reanimação até a beira do leito do paciente e esperar a chegada do médico plantonista ${ }^{11}$. Um fator importante a ser destacado é a deficiência de conhecimento dos profissionais em geral, com relação ao tema parada cardiorrespiratória ${ }^{12-13}$.

Observa-se que o enfermeiro exerce uma influência não só nas ações da equipe de enfermagem, mas também nas ações da equipe multidisciplinar, isso de acordo com o seu nível de conhecimento, sendo um fator crítico para determinar o sucesso do atendimento ${ }^{13-14}$.

Com isso, o objetivo deste estudo foi identificar a produção científica acerca da atuação do enfermeiro na parada cardiorrespiratória (PCR).

\section{MÉTODO}

Trata-se de uma pesquisa bibliográfica, do tipo revisão integrativa. Esse método permite buscar, avaliar criticamente e sintetizar as evidências disponíveis sobre o tema investigado. É muito utilizado na prática baseada 
em evidências (PBE), pois permite identificar as melhores e mais recentes evidências científicas e incorporá-las a prática clínica para a resolução de problemas ${ }^{15}$.

Os passos para estudos de revisão integrativa são: Primeira etapa: identificação do tema e seleção da hipótese ou questão de pesquisa para a elaboração da revisão integrativa; Segunda etapa: estabelecimento de critérios para inclusão e exclusão de estudos/ amostragem ou busca na literatura; Terceira etapa: definição das informações a serem extraídas dos estudos selecionados/ categorização dos estudos; Quarta etapa: avaliação dos estudos incluídos na revisão integrativa; Quinta etapa: interpretação dos resultados e Sexta etapa: apresentação da revisão/síntese do conhecimento ${ }^{15}$.

A busca na literatura foi realizada nas bases de dados: Medical Literature Analysis and Retrieval System Online (MEDLINE); Índice Bibliográfico Español de Ciencias de laSalud (IBECS); Base de Dados da Enfermagem (BDENF); e Literatura Latino-Americana e do Caribe em Ciências da Saúde (LILACS), por meio da Biblioteca Virtual de Saúde (BVS), utilizando os descritores: "ressuscitação cardiopulmonar", "enfermagem", "equipe de assistência ao paciente" e "unidades de terapia intensiva". Estes termos foram utilizados de forma conjunta e isolados usando o operador booleano AND. Na primeira busca foram encontrados 2148 artigos sem filtros e 391 com filtro.

Mediante ao exposto, uma questão surgiu para nortear o desenvolvimento deste estudo: como as pesquisas abordam a atuação do enfermeiro durante a Parada Cardiorrespiratória ( $P C R$ ) na unidade de terapia intensiva?

O período de coleta de dados ocorreu em agosto e setembro de 2015, sendo definidos como critérios de inclusão: artigos indexados nas bases de dados; nos idiomas: inglês, espanhol e português; tendo com ano de publicação o período: 2010 à 2015. Como critérios de exclusão: estudos que não possuíam texto completo disponível gratuitamente.

Após a seleção dos artigos, os mesmos foram analisados de forma crítica, expondo os resultados encontrados. Posteriormente, discutidos de modo a comparar os principais achados com os demais estudos da literatura. E por fim, a análise e interpretação dos dados deu origem às três categorias temáticas, com o intuito de facilitar a exposição e discussão dos dados da pesquisa, dentre as quais: Ensino teórico e prático; conhecimento sobre PCR e RCP; desempenho da equipe multiprofissional durante a PCR.

Realizada a seleção das obras, foram obtidos nove artigos. Com isso, na fase de interpretação, as obras foram lidas e analisadas, sendo que os eixos temáticos resultantes da análise textual foram organizados em três categorias: Ensino teórico e prático; conhecimento sobre PCR e RCP; desempenho da equipe multiprofissional durante a PCR.
Quadro 1. Seleção dos artigos na BVS no período de 2010 a 2015. Niterói, RJ, Brasil, 2016.

\begin{tabular}{|c|c|c|}
\hline Descritores & Resultado & $\begin{array}{l}\text { Artigos selecionados após } \\
\text { critérios de inclusão e exclusão }\end{array}$ \\
\hline $\begin{array}{l}\text { Ressuscitação } \\
\text { cardiopulmonar } \\
\text { and } \\
\text { Enfermagem }\end{array}$ & 139 & 6 \\
\hline $\begin{array}{l}\text { Ressuscitação } \\
\text { cardiopulmonar } \\
\text { and Equipe de } \\
\text { assistência ao } \\
\text { paciente }\end{array}$ & 65 & 1 \\
\hline $\begin{array}{l}\text { Ressuscitação } \\
\text { cardiopulmonar } \\
\text { and Unidade de } \\
\text { terapia intensiva }\end{array}$ & 163 & 1 \\
\hline $\begin{array}{c}\text { Ressuscitação } \\
\text { cardiopulmonar } \\
\text { and } \\
\text { Enfermagem } \\
\text { and Unidade de } \\
\text { terapia intensiva }\end{array}$ & 15 & 1 \\
\hline $\begin{array}{l}\text { Ressuscitação } \\
\text { cardiopulmonar } \\
\text { and } \\
\text { Enfermagem } \\
\text { and Equipe de } \\
\text { assistência ao } \\
\text { paciente }\end{array}$ & 9 & 0 \\
\hline TOTAL & 391 & 9 \\
\hline
\end{tabular}

Fonte: dados da pesquisa.

\section{RESULTADOS}

Após a leitura dos títulos e resumos dos artigos selecionados, e a partir da aplicação dos critérios de inclusão e exclusão, a amostra final foi de 9 artigos, o qual é observado no fluxograma 1.

Fluxograma 1. Caminho percorrido na identificação dos estudos investigados. Niterói, RJ, Brasil, 2016.

Busca na BVS utilizando os descritores "ressuscitação cardiopulmonar", "enfermagem", "equipe de assistência ao paciente" e "unidades de terapia intensiva".

$\downarrow$

2148 artigos

391 artigos após pareameñto

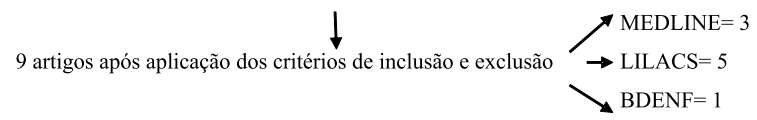

Fonte: dados da pesquisa.

A seguir, o quadro 2 traz a síntese dos artigos selecionados, por meio do título, ano, base de dados e os principais achados dos estudos.

Do total de 9 artigos levantados, 8 (88,8\%) foram realizados no Brasil e 1 (11,1\%) na Suíça, 4 (44,4\%) 
Quadro 2 Artigos selecionados para a revisão integrativa. Niterói, RJ, Brasil, 2016.

\begin{tabular}{|c|c|c|c|}
\hline Título & Ano & Base de Dados & Principais achados \\
\hline $\begin{array}{l}\text { Team coordination } \\
\text { during cardiopulmonary } \\
\text { resuscitation. }\end{array}$ & 2013 & MEDLINE & $\begin{array}{l}\text { Desempenho na ressuscitação cardiopulmonar é frequentemente } \\
\text { abaixo do padrão. Coordenação de equipe, planejamento, liderança } \\
\text { e comunicação é um poderoso processo de equipe que pode } \\
\text { influenciar o desempenho da RCP. }\end{array}$ \\
\hline $\begin{array}{l}\text { Avaliação dos registros } \\
\text { de enfermagem } \\
\text { sobre ressuscitação } \\
\text { cardiopulmonar baseada } \\
\text { no modelo Utstein }\end{array}$ & 2013 & BDENF & $\begin{array}{l}\text { Apenas a hora do óbito e hora da parada foram registradas em } 100 \% \\
\text { da amostra. Registros considerados de baixa qualidade, podendo } \\
\text { incorrer em sanções legais aos profissionais. }\end{array}$ \\
\hline $\begin{array}{l}\text { Assistência ao paciente em } \\
\text { parada cardiorrespiratória } \\
\text { em Unidade de Terapia } \\
\text { Intensiva }\end{array}$ & 2012 & LILACS & $\begin{array}{l}\text { Dos } 33 \text { profissionais que participaram do estudo, } 54,5 \% \text { não haviam } \\
\text { feito capacitação prévia sobre o tema; } 93,9 \% \text { acertaram parcialmente } \\
\text { os ritmos de parada; apenas } 15,2 \% \text { acertaram totalmente as } \\
\text { manobras de ventilação no paciente intubado. Há necessidade de } \\
\text { atualização da equipe de enfermagem. }\end{array}$ \\
\hline $\begin{array}{l}\text { Desenvolvimento } \\
\text { de Ambiente Virtual } \\
\text { de Aprendizagem } \\
\text { em Enfermagem } \\
\text { sobre ressuscitação } \\
\text { cardiorrespiratória em } \\
\text { neonatologia }\end{array}$ & 2013 & MEDLINE & $\begin{array}{l}\text { O emprego da metodologia de criação de AVA em associação ao } \\
\text { design instrucional contextualizado deu origem ao ENFNET, um } \\
\text { ambiente virtual voltado para educação continuada em enfermagem. } \\
\text { O ambiente mostrou-se útil como estratégia para auxiliar na } \\
\text { aprendizagem. }\end{array}$ \\
\hline $\begin{array}{l}\text { Efeito na Ressuscitação } \\
\text { Cardiopulmonar utilizando } \\
\text { treinamento teórico versus } \\
\text { treinamento teórico-prático }\end{array}$ & 2010 & LILACS & $\begin{array}{l}\text { Não houve diferença na avaliação teórica }(p=n s) \text {, entretanto a } \\
\text { avaliação prática foi consistentemente pior no grupo A evidenciado } \\
\text { pelos três examinadores }(p<0,05) \text {. A Utilização de vídeos de RCP e } \\
\text { aulas teóricas pode melhorar a capacidade cognitiva. }\end{array}$ \\
\hline $\begin{array}{l}\text { Proposta educacional } \\
\text { virtual sobre atendimento } \\
\text { da ressuscitação } \\
\text { cardiopulmonar no recém- } \\
\text { nascido }\end{array}$ & 2010 & LILACS & $\begin{array}{l}\text { Os módulos de ensino: Módulo } 1 \text { - Fundamentos de anatomia e } \\
\text { fisiologia cardíacas do recém-nascido; Módulo } 2 \text { - Fatores de risco } \\
\text { para ocorrência da PCR no recém-nascido; Módulo } 3 \text { - Planejamento } \\
\text { da assistência de enfermagem; Módulo } 4 \text { - Medicamentos } \\
\text { empregados na PCR no recém-nascido; e Módulo } 5 \text { - Atendimento da } \\
\text { PCR no recém-nascido. Este projeto pode contribuir com a inovação } \\
\text { do ensino em enfermagem. }\end{array}$ \\
\hline $\begin{array}{l}\text { Capacitação teórica } \\
\text { do enfermeiro para o } \\
\text { atendimento da parada } \\
\text { cardiorrespiratória }\end{array}$ & 2010 & MEDLINE & $\begin{array}{l}\text { A média das notas no grupo-A variou de forma progressiva: } 6,45 \text {; } \\
6,66 \text { e } 7,10 ; \text { e, no grupo-B, de forma oscilante: } 6,48 ; 8,36 \text { e } 8,0 ; \\
\text { etapas II e III }(p<0,001) \text {. Concluiu-se que o grupo-B foi superior ao } \\
\text { grupo-A. }\end{array}$ \\
\hline $\begin{array}{l}\text { Atuação do Time de } \\
\text { Resposta Rápida no } \\
\text { processo educativo de } \\
\text { atendimento da parada } \\
\text { cardiorrespiratória }\end{array}$ & 2013 & LILACS & $\begin{array}{l}\text { No grupo de enfermeiros, a nota média no pré-teste foi de } 5,83 \\
\pm 1,95 \text { e } 8,87 \pm 1,25 \text {, no pós-teste. Dentre os fisioterapeutas, as } \\
\text { notas médias foram } 4,02 \pm 1,85 \text { e } 9,00 \pm 1,24 \text {, no pré e pós-teste } \\
\text { respectivamente. No grupo de auxiliares e técnicos de enfermagem, } \\
\text { a nota de pré-teste foi de } 4,85 \pm 1,93 \text { no pré-teste e } 7,70 \pm 1,72 \text { no } \\
\text { pós-teste. Os resultados mostram deficiência no conhecimento da } \\
\text { equipe multiprofissional. }\end{array}$ \\
\hline $\begin{array}{l}\text { Organização do trabalho } \\
\text { e seus reflexos na } \\
\text { atuação dos trabalhadores } \\
\text { de enfermagem } \\
\text { em ressuscitação } \\
\text { cardiopulmonar }\end{array}$ & 2012 & LILACS & $\begin{array}{l}\text { Há um distanciamento entre o trabalho prescrito e o real. } \\
\text { Repercussões psicofísicas percebidas: irritabilidade, ansiedade, } \\
\text { fadiga, lombalgia. Há necessidade de discutir, avaliar e intervir } \\
\text { no processo laboral a fim de que a atividade de RCP seja melhor } \\
\text { operacionalizada. }\end{array}$ \\
\hline
\end{tabular}

Fonte: dados da pesquisa.

publicados em 2013, 3 (33,3\%) em 2010 e 2 (22,2 \%) em 2012.

Em relação à formação dos autores, 5 (55,5\%) enfermeiros e em 4 (44,4\%) a formação dos autores não foi identificada, sendo associado a alguma instituição, entre as quais: Universidades e Hospitais.
Quanto ao tipo de estudo desenvolvido, 2 (22,2\%) estudos de pesquisa aplicada com produção tecnológica; 2 (22,2\%) estudos de investigação prospectiva, intervencionista e comparativa; 1 (11,1\%) revisão da literatura; 1 (11,1\%) estudo descritivo transversal, retrospectivo; 1 (11,1\%) estudo descritivo e quantitativo; 
1 (11,1\%) estudo qualitativo, descritivo e exploratório; 1 $(11,1 \%)$ estudo de corte transversal.

Em relação à região e país, 5 (55,5\%) foram publicados no Sudeste do Brasil, 2 (22,2\%) no Nordeste, 1 (11,1\%) no Centro-Oeste e $1(11,1 \%)$ na Suíça. Quanto às revistas, 2 (22,2\%) foram publicados na Revista da Rede de Enfermagem do Nordeste (RENE), 2 (22,2\%) na Revista da Escola de Enfermagem da USP, 1 (11,1\%) no Journal of Critical Care, 1(11,1\%) na Revista Brasileira de Enfermagem, 1 (11,1\%) Revista Enfermagem UERJ, 1(11,1\%) Revista da Sociedade Brasileira de Clínica Médica e 1 (11,1\%) Arquivos Brasileiros de Cardiologia.

Após a leitura na íntegra dos artigos foram encontrados $4(44,4 \%)$ relacionados ao ensino teórico-prático voltado para os profissionais da equipe de enfermagem; 3 (33,3\%) que abordaram o conhecimento dos profissionais da área de saúde (equipe multiprofissional e de enfermagem) sobre PCR e RCP e 2 (22.2\%) que falavam sobre o desempenho da equipe multiprofissional e/ou equipe de enfermagem durante e após a PCR.

\section{DISCUSSÃO}

\section{Ensino teórico-prático}

Nessa categoria, identificou-se quatro artigos que abordavam o ensino teórico-prático, em que se observou nos estudos o desenvolvimento de ferramentas virtuais para o uso em treinamentos e a comparação entre grupos que receberam treinamento e os que não receberam.

Foi desenvolvida uma ferramenta virtual para o ensino de ressuscitação cardiorrespiratória em neonatologia para ser utilizado na educação continuada em enfermagem. Esse ambiente virtual de ensino mostrou-se como uma boa estratégia para auxiliar na aprendizagem, desenvolver habilidades e capacitar a equipe de enfermagem ${ }^{16}$.

Em outro estudo ${ }^{17}$, comparou-se dois grupos (A e B), onde no grupo $A$ os voluntários participaram do treinamento teórico de RCP e desfibrilação externa automática, apenas com aula teórica e vídeo usado nos cursos de SBV da American Heart Association (BLS-AHA). No grupo B os voluntários tiveram um curso regular teórico-prático de BLS-AHA. Após os cursos os participantes dos dois grupos foram submetidos à avaliação teórica e prática.

Foi constatado não haver diferença na avaliação teórica, porém a avaliação prática foi consistentemente pior no grupo A que tinha participantes mais novos e com menos tempo de formação. Concluiu-se que aulas e vídeos podem levar a RCP de boa qualidade, o que pode melhorar a sobrevida na PCR dentro e fora do hospital. Por outro lado, foi demonstramos que somente treinamento teórico não é capaz de produzir RCP de boa qualidade ${ }^{17}$.

Desenvolveu-se uma proposta educacional virtual, por meio de uma plataforma chamada TelEduc, voltada para o atendimento ao recém-nascido, tendo como resultado final um produto tecnológico para auxiliar no ensino.
Concluiu-se que essa ferramenta pode contribuir com a inovação do ensino em enfermagem, já que o atendimento a ressuscitação cardiopulmonar do recém-nascido é um tema muito relevante ${ }^{18}$.

Em outro artigo, foi aplicado um programa de capacitação teórica para enfermeiros na ressuscitação cardiopulmonar, sendo comparado o conhecimento teórico do grupo A- controle e grupo B-experimental. Conclui-se que o grupo $B$ apresentou conhecimentos superiores aos do ao grupo $A$, onde pelos resultados foi sugerido que 0 programa de capacitação deve ser aplicado regularmente, com uma periodicidade trimestral ou semestral, pois, foi observado declínio do conhecimento com o passar do tempo ${ }^{19}$.

Identificou-se que o ensino teórico-prático regular mantém um bom nível de conhecimento do profissional. A criação de ferramentas para auxiliar esse aprendizado tem se mostrado eficaz como estratégia de ensino, sendo que deve haver um equilíbrio entre a teoria e a prática.

É primordial para a recuperação de um paciente em $P C R$, o seu rápido reconhecimento e intervenção da equipe de modo organizado. A RCP incorreta está associada a uma taxa de sobrevida menor quando comparada com a realizada de maneira correta ${ }^{20-22}$.

Um adequado treinamento da equipe de enfermagem, em especial a que atua em UTI e emergência, é vital para $o$ atendimento em PCR. Identificar o conhecimento teórico e prático da equipe a respeito de PCR e RCP é um requisito importante para planejar o treinamento em serviço. Esse treinamento deve atender o que preconiza os Guidelines para a reanimação cardiorrespiratória. Atualmente tem-se o Guideline de 2015 para RCP e emergências cardiovasculares, que fez algumas alterações no guideline de $2010^{23}$.

\section{Conhecimento sobre parada cardiorrespiratória e ressuscitação cardiopulmonar}

Nessa categoria, identificou-se três artigos sobre conhecimento de PCR e RCP, em que foram avaliados desde a qualidade dos registros nos prontuários até o conhecimento de profissionais da equipe de enfermagem e fisioterapeutas.

Foi avaliada a qualidade dos registros de enfermagem sobre ressuscitação cardiopulmonar (RCP), onde apenas a hora do óbito e a hora da parada cardiorrespiratória foram registradas em $100 \%$ dos prontuários. Não foi registrado treinamento dos profissionais em Suporte Avançado de Vida. Foi observado que os registros foram de baixa qualidade, visto que a maioria dos aspectos de atendimento a PCR não foi registrada como, por exemplo, a desfibrilação, uso de drogas, doses utilizadas. Devido aos registros de baixa qualidade, pode haver sanções legais aos profissionais, entre eles o enfermeiro, e impossibilidade de comparação da efetividade das manobras com outros centros ${ }^{24}$. 
Realizou-se um estudo que avaliou o conhecimento da equipe de enfermagem de uma unidade de terapia intensiva (UTI) em relação a PCR, baseado nos protocolos de suporte básico e avançado de vida, sendo avaliado um total de 33 profissionais, sendo que 54,5\% não haviam feito capacitação prévia sobre o tema. Foi constatado um baixo índice de acertos e com isso demonstrou-se a necessidade de atualização da equipe de enfermagem, com capacitação teórico-prática de maneira periódica e avaliações sistemáticas da atuação da equipe ${ }^{25}$.

0 conhecimento da equipe multiprofissional (enfermagem e fisioterapia) foi avaliado no reconhecimento e tratamento da PCR, por meio de um questionário. Depois da sua aplicação, foi realizado treinamento com time de resposta rápida e feita avaliação após o treinamento. Observou-se maior acerto das questões após o treinamento em todos os grupos. Os resultados mostraram, deficiência no conhecimento da equipe multiprofissional diante das situações de $P C R$, tendo como recomendação importante a realização de programas de educação permanente ${ }^{26}$.

A importância de manter o ensino teórico-prático regular, para a equipe, mostrou-se essencial mais uma vez. Percebeu-se um déficit de conhecimento principalmente nos profissionais da saúde sem treinamento prévio, influenciando inclusive no registro da PCR e com isso dificultando comparações e novos estudos para melhoria da prática.

Se o registro não é realizado de maneira adequada, não há informação adequada para a tomada de decisões e, muitas vezes, se desconsidera o processo de trabalho realizado. É importante ressaltar que o uso do "debriefing" pode ser usado como estratégia importante para estimular o registro das ações, bem como para levar a equipe a um processo reflexivo sobre a sua própria prática assistencial. 0 debriefing tem sido muito utilizado como estratégia de educação dos profissionais que atuam na urgência e emergência, onde são reunidos todos os profissionais que atuaram no atendimento à $P C R$ para registrar e discutir todo o processo de atendimento ao paciente ${ }^{8}$.

Foi recomendado que a equipe de enfermagem deve buscar a reciclagem com relação às manobras de ressuscitação cardiopulmonar, assim como, ter domínio do conteúdo existente no carro de emergência e manuseio do equipamento ${ }^{27}$.

0 enfermeiro intensivista por ser, frequentemente, quem avalia em primeiro lugar o paciente vítima de PCR, é de vital importância nos esforços para a reanimação. Tanto o enfermeiro como sua equipe devem assistir o paciente, oferecendo ventilação e circulação, além disso, esses profissionais devem adquirir habilidades que os capacitem a prestar assistência adequada ${ }^{8,23}$.

A formação do profissional e o tempo de atuação em unidade de terapia intensiva, influenciam no índice de acertos das questões avaliadas ${ }^{23}$. É recomendado que o profissional para atuar em uma UTI, deva ter anos de experiência ${ }^{28}$. Sabe-se que o enfermeiro é mediador nessa atuação. Um enfermeiro que não domina as habilidades necessárias para atuação em uma PCR, pode promover o erro da equipe, o que pode ser prejudicial para o paciente ${ }^{8}$.

\section{Desempenho da equipe multiprofissional durante a parada cardiorrespiratória}

$\mathrm{Na}$ última categoria, identificou-se dois artigos, que abordavam o desempenho da equipe de enfermagem e multiprofissional em relação à coordenação e aos fatores que dificultavam e facilitavam sua atuação durante a RCP.

Um dos estudos identificou fatores facilitadores e dificultadores que são enfrentados pelos trabalhadores de enfermagem na atuação em RCP e analisou as repercussões psicofísicas dessa atividade na saúde dos trabalhadores. Foi aplicado uma entrevista semiestruturada e as informações foram analisadas através do método de análise de conteúdo. 0 estudo evidenciou que os trabalhadores de enfermagem realizavam a atividade de RCP em condições de precariedade, apresentando, assim, repercussões psicofísicas como irritabilidade, ansiedade, fadiga, lombalgia. Os fatores dificultadores enfrentados na atuação da PCR foram relacionados à infraestrutura inadequada e organização do trabalho (ex: déficit de trabalhadores de enfermagem, capacitação e experiência profissional deficitária e relações conflituosas entre os profissionais) $)^{29}$.

Por outro lado, os fatores que facilitavam o atendimento durante a PCR, foram: o conhecimento técnico das equipes, mudanças estruturais na enfermagem, aquisição de novos leitos e divisórias e a presença de médico na enfermaria durante a PCR. Diante disso, foi recomendado, em especial à enfermagem, aos gestores e ao coletivo profissional, refletirem e discutirem sobre a organização do trabalho hospitalar, com objetivo de torná-lo mais racional e favorável à saúde do trabalhador ${ }^{29}$.

Em uma revisão de literatura sobre coordenação e desempenho da equipe durante a RCP, foi notado que o desempenho durante a RCP é frequentemente abaixo do padrão. Esse mau desempenho pode ser explicado pela falta de coordenação entre os membros da equipe. Essa perda de coordenação é devido a uma gestão insuficiente entre os membros da equipe de RCP. 0 estudo concluiu que a coordenação, planejamento e liderança são um processo poderoso que influencia o desempenho da equipe durante a PCR, sendo hora de reconhecer a necessidade de abordar esses assuntos de forma mais explícita, durante os treinamentos e estratégias de educação ${ }^{30}$.

Pode-se constatar que o desempenho da equipe durante a PCR é influenciada negativamente ou positivamente por vários fatores, porém pode-se destacar a coordenação, infraestrutura, quantidade de trabalhadores e liderança. A $P C R$, sendo um processo reversível, necessita de organização, treinamento e trabalho em equipe, além do conhecimento técnico, sendo necessário um olhar mais amplo8. 
Para manter a equipe de enfermagem preparada para atuar em PCR, é necessário a realização de capacitação e simulações periódicas. A distribuição coordenada das tarefas, rapidez, manter o nível de tranquilidade, reunir materiais e equipamentos necessários, são imprescindíveis para a reanimação, sendo recomendado a atualização da equipe na execução das manobras ${ }^{21,31}$.

Estudos demonstram que o enfermeiro e equipe de enfermagem, apresentam um desconhecimento considerável sobre os conceitos de PCR, identificação de vítima com PCR, sequência do suporte básico de vida (CAB) e fármacos a serem administrados. Essa falta de conhecimento pode gerar algumas situações que irão interferir sobre toda a equipe multiprofissional durante a PCR. Nesse contexto, o enfermeiro é mediador, pois ele é responsável pela provisão dos matérias (conferir carrinho de parada, drogas a serem preparadas, materiais em geral). Um enfermeiro que desconhece, em parte, esse processo, pode promover o erro da equipe multiprofissional. Esse desconhecimento do enfermeiro pode contribuir para a desorganização do processo de trabalho que envolve o atendimento a vítima que está em PCR. Percebe-se então que o modo como o enfermeiro vai administrar esse momento, pode/vai influenciar na sintonia da equipe multidisciplinar8.

\section{CONCLUSÃO}

Os estudos que foram encontrados na literatura estão voltados para o desenvolvimento de ferramentas que auxiliem no ensino teórico-prático e para medir o nível de conhecimento dos profissionais sobre PCR, sendo evidenciado a necessidade de treinamento e capacitação frequentes, devido ao baixo grau de conhecimento de boa parte dos sujeitos que participaram dos estudos.

Foi evidenciado que para um bom desempenho durante a RCP, a equipe deve ter boas condições de trabalho, como por exemplo, acessibilidade a tecnologias e estrutura física do ambiente de trabalho. O planejamento e liderança também influenciam esse desempenho. Uma equipe bem treinada também terá um melhor desempenho, onde o mesmo deve atender o que preconiza os Guidelines para a reanimação cardiorrespiratória.

Em contrapartida, nenhum estudo abordou especificamente a atuação ou liderança do enfermeiro durante a RCP, falando apenas superficialmente da sua importância por ser um dos primeiros da equipe a detectar uma possível $P C R$, sendo necessário explorar mais esse assunto.

Considerando o quantitativo de artigos sobre o tema, sugere-se realização de novos estudos nos diversos campos das instituições de saúde para dar maior visibilidade a uma situação que requer competência técnico cientifica tanto do enfermeiro quanto dos demais membros da equipe de saúde em face da magnitude da ocorrência da PCR e suas repercussões para os pacientes.

\section{REFERÊNCIAS}

1. Alves FG, Maia LFS. A importância do treinamento em PCR e RCP para os profissionais de enfermagem em unidade de terapia intensiva. Rev Recien [Internet]. 2011 [acesso em 20 de ago 2015];1(2):11-16. Disponível em: http://www.recien. com.br/online/index.php/Recien/article/view/21.

2. Sociedade Brasileira de Cardiologia. I Diretriz de Ressuscitação Cardiopulmonar e Cuidados Cardiovasculares de Emergência da Sociedade Brasileira de Cardiologia. Arq Bras Cardiol [Internet]. 2013 [acesso em 20 ago 2015];101(2):1-221. Disponível em: http://publicacoes. cardiol.br/consenso/2013/Diretriz_Emergencia.pdf.

3. Braz JRC, Castglia YMM. Temas de anestesiologia. $2^{\text {a }}$ ed. São Paulo: UNESP, 2000.

4. American Heart Association - AHA. Guidelines CPR e ECC. Destaques das Diretrizes da

5. American Heart Association 2010 para RCP e ACE; 2010. Disponível em:

6. http://guidelines.ecc.org/pdf/KJ0872\%20ECC\%20 Guideline\%20Highlights\%202010\%20Portugue-Brazilian. pdf.

7. American Heart Association -AHA. Guidelines CPR e ECC. Destaques das Diretrizes da American Heart Association 2015 para RCP e ACE; 2015. Disponível em: https://eccguidelines. heart.org/wp-content/uploads/2015/10/2015-AHAGuidelines-Highlights-Portuguese.pdf.

8. Berg MD, Schexnayder SM, Chameides L.Part 13: pediatric basic life support: 2010 American Heart Association Guidelines for Cardiopulmonary Resuscitation and Emergency Cardiovascular Care. Circulation 2010; 122(Suppl 3): S862-S875.

9. Hudak MC, Gallo MB, Benz JJ. Cuidados Intensivos de Enfermagem: uma abordagem holística. $2^{\text {a }}$ Ed. Rio de Janeiro: Artmed; 1994.

10. Rocha FAS, Oliveira MCL, Cavalcante RB, Silva PC, Rates HF. Atuação da equipe de enfermagem frente à parada cardiorrespiratória intra-hospitalar. Rev Enferm Cent O Min [Internet]. 2012 [acesso em 20 ago 2015];2(1):141150. Disponível em: http://www.seer.ufsj.edu.br/index.php/ recom/article/view/100/265.

11. Feitosa-Filho GS,Feitosa GF,Guimarães HP,Lopes RD,JúniorRM, Souto FA et al. Atualização em Reanimação Cardiopulmonar: $\mathrm{O}$ que mudou com as novas diretrizes. Rev bras ter intensiva [Internet]. 2006 [acesso em 20 ago 2015];18(2):177-185. Disponível em: http://www.scielo.br/scielo.php?script=sci_ arttext\&pid=S0103-507X2006000200011.

12. Bertoglio VM, Azzolin K, Souza EN, Rabelo ER. Tempo decorrido do treinamento em parada cardiorrespiratória e o impacto no conhecimento teórico de enfermeiros. Rev Gaúcha Enferm [Internet]. 2008 [acesso em 20 ago 2015];29(3):454460. Disponível em: http://seer.ufrgs.br/index.php/ RevistaGauchadeEnfermagem/article/view/6774/4077.

13. Santiago PSN. Reanimação cardiopulmonar: habilidades afetivas da equipe de enfermagem em Terapia Intensiva [dissertação]. Belo Horizonte: Escola de Enfermagem da Universidade Federal de Minas Gerais; 2006.

14. Cunha CM, Toneto MAS, Pereira EBS. Conhecimento teórico dos enfermeiros de hospital público sobre reanimação 
cardiopulmonar. Biosci J [Internet]. 2013 [acesso em 20 ago 2015]; 29(5):1395-1402. Disponível em: http://www.seer.ufu. br/index.php/biosciencejournal/article/view/17175/13036.

15. Alves CA, Barbosa CNS, Faria HTG. Parada cardiorrespiratória e enfermagem: o conhecimento acerca do suporte básico de vida. Cogitare Enferm. 2013; 18(2):296-301.

16. Wehbe G, Galvão MC. Aplicação da liderança situacional em enfermagem de emergência. Rev bras enferm [Internet]. 2005 [acesso em 20 ago 2015];58(1):33-38. Disponível em: http://www.scielo.br/scielo.php?script=sci_ arttext\&pid=S0034-71672005000100006.

17. Mendes KDS, Silveira RCCP, Galvão CM. Revisão integrativa: método de pesquisa parta a incorporação de evidências na saúde e na enfermagem. Texto contexto - enferm [Internet]. 2008 [acesso em 20 ago 2015];17(4):758-64. Disponível em: http://www.scielo.br/scielo.php?script=sci_ arttext\&pid=S0104-07072008000400018.

18. Rodrigues RCV, Peres HHC. Desenvolvimento de Ambiente Virtual de Aprendizagem em Enfermagem sobre ressuscitação cardiorrespiratória em neonatologia. Rev esc enferm USP [Internet]. 2013 [acesso em 20 ago 2015];47(1):231-7. Disponível em: http://www.scielo.br/scielo.php?script=sci_ arttext\&pid=S0080-62342013000100030.

19. Miotto HC, Camargos FRS, Ribeiro CV, Goulart EMA, Moreira MCV. Efeito na ressuscitação cardiopulmonar utilizando treinamento teórico versus treinamento teórico-prático. Arq Bras Cardiol [Internet]. 2010 [acesso em 20 ago 2015];95(3):328-331. Disponível em: http:// www.scielo.br/scielo.php?script=sci_arttext \& $p i d=S 0066$ 782X2010001300008.

20. Gonçalves GR, Peres HHC, Rodrigues RC, Tronchin DMR, Pereira IM. Proposta educacional virtual sobre atendimento da ressuscitação cardiopulmonar no recém-nascido. Rev esc enfermUSP[Internet].2010[acessoem20ago2015];44(2):41320. Disponível em: http://www.scielo.br/scielo. php?script=sci_arttext \&pid=S0080-62342010000200025.

21. Bellan MC,Araújo II,Araújo S.Capacitação teórica do enfermeiro para o atendimento da parada cardiorrespiratória. Rev bras enferm [Internet]. 2010 [acesso em 20 ago 2015];63(6):101927. Disponível em: http://www.scielo.br/scielo. php?script=sci_arttext \& pid=S0034-71672010000600023.

22. Cirenza C, Knobel E, Feher J. Reanimação Cardiorrespiratória. In: Knobel E. Condutas no Paciente Grave. Rio de Janeiro: Atheneu; 1994.

23. Araújo IEM, Araújo S. Ressuscitação Cardiorrespiratória. In: Cintra EA, Nishide VM, Nunes WA. Assistência de Enfermagem ao Paciente Gravemente Enfermo. São Paulo: Atheneu; 2001.

24. Laselva RG, Moura Júnior DF. Parada Cardiorrespiratória e Reanimação. In: Knobel E, Laselva RG, Moura Júnior DF. Terapia Intensiva: Enfermagem. São Paulo: Atheneu; 2005.

25. Zanini J, Nascimento ERP, Barra DCC. Parada e reanimação cardiorrespiratória:conhecimentos da equipe de enfermagem em unidade de terapia intensiva. Rev bras ter intensiva [Internet]. 2006 [acesso em 20 ago 2015];18(2):143-7. Disponível em: http://www.scielo.br/scielo.php?script=sci_ arttext\&pid=S0103-507X2006000200007.

26. Grisante DL, Silva ABV, Ayoub AC, Belinelo RGS, Onofre PSC, Lopes CT. Avaliação dos registros de enfermagem sobre ressuscitação cardiopulmonar baseada no modelo
Utstein. Rev Rene [Internet]. 2013 [acesso em 20 ago 2015];14(6):1177-84. Disponível em: http://www.producao. usp.br/handle/BDPI/44254.

27. Moura LTR, Lacerda LCA, Gonçalves DDS, Andrade RB, Oliveira YR. Assistência ao paciente em parada cardiorrespiratória em Unidade de Terapia Intensiva. Rev Rene [Internet]. 2012 [acesso em 20 ago 2015];13(2):419-27. Disponível em: http://www.redalyc.org/articulo.oa?id=324027981018.

28. Veiga VC, Carvalho JC, Amaya LEC, Gentile JKA, Rojas SSO. Atuação do Time de Resposta Rápida no processo educativo de atendimento da parada cardiorrespiratória. Rev Soc Bras Clin Med. 2013;11(3):258-62.

29. Coelho OR, Cirillo W, Barbeiro RMD. Ressuscitação cardiopulmonar. Rev.Soc.Card. 1997; 7:1-3.

30. Cheregatti AL. Enfermagem em unidade de terapia intensiva. $2^{a}$ ed. São Paulo: Martinari; 2011.

31. Sá CMS, Souza NVDO, Lisboa MTL, Tavares KFA. Organização do trabalho e seus reflexos na atuação dos trabalhadores de enfermagem em ressuscitação cardiopulmonar. Rev enferm UERJ [Internet]. 2012 [acesso em 20 ago 2015];20(1):50-5. Disponível em: http://www.e-publicacoes.uerj.br/index.php/ enfermagemuerj/article/view/3975/2758.

32. Kolbe M,Grande B.Team coordination during cardiopulmonary resuscitation. Journal of critical care [Internet]. 2013 [acesso em 20 ago 2015];28(4):522-3. Disponível em: https:// www.researchgate.net/publication/236917991_Team_ coordination_during_cardiopulmonary_resuscitation.

33. Ovalle CCIS, Araújo S, Oliveira RARA, Dragosavac D. A importância do treinamento prévio no uso do desfibrilador externo automático por fisioterapeutas e enfermeiros. RBTI [Internet]. 2005 [acesso em 20 ago 2015];17(2):1125. Disponível em: http://www.amib.com.br/rbti/download/ artigo_20106171741.pdf. 